\title{
MEGRENDÜLÉS \\ Affektivitás, nyelvi erő és erőszak Pszeudo-Longinosznál
}

\section{Az ekpléxisz (megrendítés/megrendülés) szó}

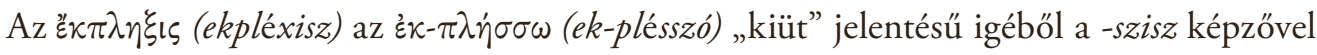
képzett nomen actionis. Az ige már Homérosznál is többször előfordul mentális hatásra, mégpedig valamilyen felkavaró-megzavaró mentális hatásra (és ennek nyomán ilyen állapotra $)^{1}$ vonatkoztatva „megijeszt, megrémít”, „megdöbbent” jelentésben; passzívban ennek megfelelően a bekövetkezett hatást jelölték vele, és „megijed, megrémül”, „megdöbben”, sőt „magán kívül van”, „megrendül” jelentésben használták (például Iliasz XVI. 403; Odüsszeia XVIII. 231). Ami valakit megrémít vagy megrendít, az lehet valamilyen hirtelen bekövetkező sokk (Aiszkhülosz, Perzsák 290), de ugyanígy lehet valamilyen hirtelen föllépő ellenállhatatlan affektus is, például a szerelmi szenvedély (Euripidész, Hippolütosz 38; Médeia

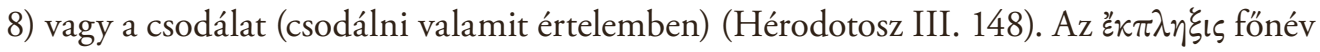
(„megrendítés” és „megrendülés”) is előfordul már Kr. e. 5. századi költői és prózai szövegekben is Aiszkhülosztól a Corpus Hippocraticumon át Thuküdidészig. ${ }^{2}$ Arisztophanésznál a Békákban a szó esztétikai vagy irodalomkritikai összefüggésben kerül elő. Euripidész az Aiszkhülosszal folytatott nevezetes agón egy pontján (962) azzal védekezik a színházi isten, Dionüszosz mint alvilági bírája előtt, hogy ő, szemben Aiszkhülosszal, nem rémítette

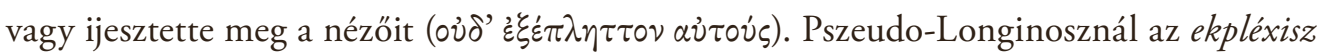
az úgynevezett $e k$-szavak csoportjának része, amelyek mindannyian valamilyen eltérésre, szó szerint $k i$-térésre és ezzel rokon képzetekre utalnak. ${ }^{3}$

1 Casper de Jonge a „mental disturbance” kifejezést használja erre: Casper C. de Jonge, Ps.-Longinus on Ecstasy. Author, Audience, and Text = Experience, Narrative, and Criticism in Ancient Greece. Under the Spell of Stories, szerk. Jonas Grethlein - Luuk Huitink - Aldo Tagliabue, Oxford UP, Oxford, 2020, 148. - A tanulmány megírását az NKFIH 120375 és 128492 számú pályázat támogatta.

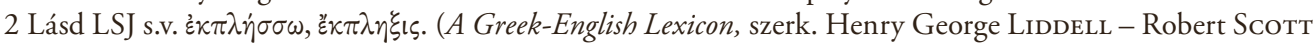
- Henry Stuart Jones, Clarendon, Oxford, 1996.)

3 James I. Porter, The Sublime In Antiquity, Cambridge UP, Cambridge, 2016, 181: eksztaszisz; ekphülosz: „ferdén nőtt”, különös, ijesztő; ekpléxisz, ekpléktikon (Porternél: „schocking”); ekbainó: kilép, túllép; exokhé: kiemelkedés, csúcspont; ekpatheia: erős szenvedély. 


\section{Rövid fogalomtörténet: Gorgiasz, Platón, Arisztotelész}

Az ekpléxisz már mint fogalom jelenik meg a Kr. e. 5-4. század elméletíróinál, mégpedig esztétikai, retorikai és poétikai kontextusban is, összefoglalólag és az antik tárgyalásmódhoz jobban illeszkedően: a szónoki vagy költői előadás, olykor a nyelv, a beszéd hatékony alakításának hatáselméleti kifejezéseként. Gorgiasz Helené dicsérete címü beszédének hatása Pszeudo-Longinoszra nyilvánvaló és a szakirodalomban is gazdagon tárgyalt, fóként ami a beszéd erejét, hatalmát, valamint affektív hatását, illetve mágikus erejét illeti (Gorgiasz

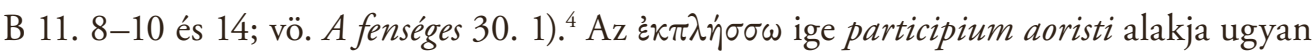
nem közvetlenül a beszéd hatásának eredményére vonatkoztatva, de mégis az azzal részleges párhuzamba állított látás hatásaként jön elő Gorgiasznál: ha „a látás” egymással szemben teljes fegyverzetben hadrendbe felsorakozott katonákat „pillant meg”, akkor megzavarodik és megrémül, és „megzavarja és megrémíti a lelket. Ezért aztán az emberek sokszor a jövőbeli

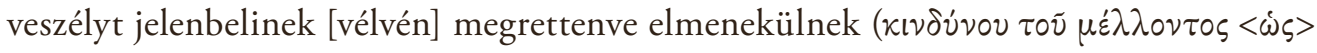

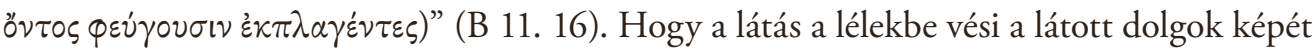
(Gorgiasz B 11. 17), annak párhuzamát Pszeudo-Longinosznál a phantaszia tárgyalásánál találjuk meg, s a költői phantaszia célja nála éppenséggel az ekpléxisz lesz (15. 2).

Platón hatása $A$ fenséges címü irat szerzőjére ugyancsak kézenfekvő, és közhely a szakirodalomban, fóként ami az enthusziaszmosz és a hatásátvitel elgondolását illeti (13. 2).5 De ugyanígy a nyelv nem szemantikai elemeinek az a felfogása is, amely ezek hatását az elvarázsolással, megigézéssel - vagyis mágikus erővel - hozza összefüggésbe $(30.1 ; 39$. 3; vö. például Platón Törvények 664b, 665c, 666c, 659e, 840c). Maga az ekpléxisz, illetve lényegesen többször az ekplésszó igei alak is előfordul Platónnál, például a szépség (Lakoma 211d1-8), de ugyanígy az Erósz megtapasztalásának (Lakoma 192b5-c2) vagy valamiféle metafizikai tapasztalat megrendítő lelki hatásának a megnevezésére (Phaidrosz 250a6-b1). Az Iónban pedig kifejezetten olyan szövegösszefüggésben fordul elő az ekplésszó, amely közel van ahhoz, ahogyan Pszeudo-Longinosz használja a fogalmat. Szókratész ugyanis itt a rhapszódosz előadásának hatását nevezi megrendítőnek: „Amikor az eposzokat szépen

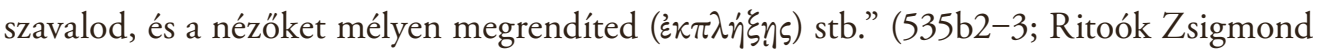
fordítása). ${ }^{6}$ Ebben a hatásban Platónnál persze nemcsak a nyelv, hanem az előadás egésze részt vesz, miközben Pszeudo-Longinosz kifejezetten a nyelvi hatásra összpontosít művében.

\footnotetext{
4 Lásd például legújabban Uo., 316-317. A fenséges címủ munkára a továbbiakban a cím megadása nélkül hivatkozom, a caputok és a paragrafusok számát is arab számmal adom meg.

5 Az enthusziaszmosz szókincséhez lásd még 3. 2, 15. 1.

6 Platón, Ión. Menexenosz, ford. Ritoóx Zsigmond (Ión), Kövendi Dénes (Menexenosz). Az Ión jegyzeteit és utószavát Riтоóк Zsigmond írta, a Menexenosz fordítását ellenőrizte, a jegyzeteket és az utószót írta Steiger Kornél, Atlantisz, Budapest, 2000.
} 
Arisztotelész a Topika IV. könyvében az ekpléxiszt a csodálat vagy megdöbbenés (thau-

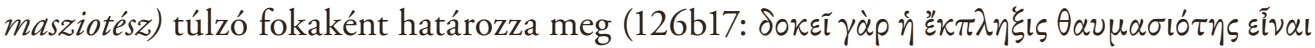

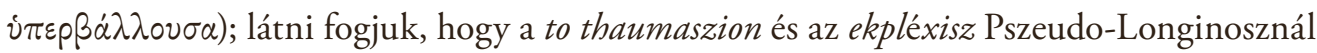
is közel kerül egymáshoz (1. 4, rövidesen idézni fogom). Az igei alak is többször előfordul a Filozófusnál, egyebek mellett retorikai összefüggésben is (Rétorika 1408a25, 1385b33; vö. a nem arisztotelészi, de az ő elgondolása által befolyásolt, peripatetikus Alexandroszhoz írott Rétorika 1433a12-t). A Poétikában háromszor használja a fogalmat Arisztotelész (kétszer a melléknévi, egyszer a fónévi alakot). A 14. és 16. fejezetben az újrafelismerés összefüggésében kerül elő (1454a4: ekpléktikon, 1455a17: ekpléxisz), egyértelműen az anagnóriszisz megfelelő (illetve minél erősebb) hatásának jelölésére. Ezeken a helyeken az ekpléxisznek elsősorban talán az események váratlanságával összekapcsolódó megdöbbentő mozzanata lesz az elsődleges (ami persze bizonyos esetekben a megrendülésnek/megrendítésnek is szerves része). Figyelemreméltó, de ugyancsak röviden jelezhető a 25. fejezet megfogalmazása: „Ha [a költő] lehetetlenséget alkot, hibát követ el. Mégis helyes, ha célját eléri (a célt már korábban megmondtuk), ha tehát így akár azt [a részt, ahol a „hibát” elkövette], akár

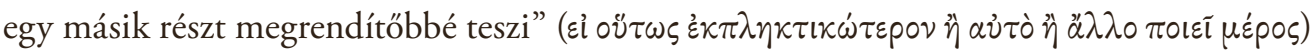
(1460b23-26; Ritoók Zsigmond fordítása). ${ }^{7}$ Amikor Arisztotelész a korábban meghatározott célról beszél, akkor itt minden bizonnyal a 9. fejezetnek arra a megfogalmazására utal, amely a váratlanság mozzanata révén kiváltott „csodálatossal” (to thaumaszton; „meglepőnek”, „megdöbbentőnek” is lehetne fordítani) egyenesen a tragédia által kiváltandó két alapvető affektust, a félelmet és a részvétet kapcsolja össze (1452a1-5). Az ekpléxisz ilyen módon a tragédiaelmélet hatáselméleti elgondolásának középpontjával áll szoros összefüggésben.

\section{Az ekpléxisz Pszeudo-Longinosznál}

Mielőtt rátérnék az ekpléxisz vizsgálatára Pszeudo-Longinosznál, röviden vázolom azt a koncepcionális keretet, amelyben a megrendülés mint a fenséges hatását - az eksztaszisz mellett - megragadó egyik fogalom elhelyezkedik. A fenséges hatásának alapszerkezetét Pszeudo-Longinosznál egy kettősség rajzolja ki. Egyfelől ott van a fenséges pillanatnyi, intenzív, a hallgatót vagy olvasót ellenállhatatlanul magával ragadó, affektív hatása, amelyet egyfajta „stíluspatológiai” elemzéssel mutat ki. A megrendülés („kiütés”) fogalmi metaforája ehhez kapcsolódik. Ezt a hatást Gumbrecht nyomán nem hermeneutikainak

7 Arisztotelész, Poétika és más költészettani irások, ford. Ritoóк Zsigmond; szerk. és jegyz. Bolonyai Gábor, PannonKlett, Budapest, 1997.

8 Manfred Funrmann, Einführung in die antike Dichtungstheorie, Wissenschaftliche Buchgesellschaft, Darmstadt, 1973, 141: „Analyse stilpathologischer Phänomene”. 
is nevezhetjük. ${ }^{9}$ De ez csak a fenséges hatásának egyik oldala. A másik oldalon, amely ugyanakkora hangsúlyt kap Pszeudo-Longinosznál, ott van a fenséges hermeneutikainak nevezhető hatása. Ezt a hatást a pillanatnyival, a pillanatnyisággal szemben a tartósság jellemzi (7. 3); a hirtelen intenzitással szemben ebben a hosszú távú, a szellemet tartósan lekötő megragadottság van jelen (7. 3); az affektív mozzanattal pedig a kognitív vagy értelmező műveleteket igénylő megértés áll szemben (39. 3). ${ }^{10}$ A mü koncepciójának egésze szempontjából mindkét mozzanat egyaránt fontos. ${ }^{11}$ Pszeudo-Longinosz ezt a kettősséget nem érzékeli ellentmondásosnak, elgondolásában a kettő jól megfér egymással, s együtt ad számot a fenséges komplex hatásáról. A fenségesben kifejtett elméletnek ezt a kettősségét a legalaposabban Stephen Halliwell tárta fel, aki ecstasy and truth metszéspontjaként beszélt róla. ${ }^{12}$ Fontos tehát hangsúlyozni, hogy amikor a továbbiakban az ekpléxiszként megnevezett

9 Hans Ulrich Gumbrecht, A jelenlét elöállitása. Amit a jelentés nem közvetit, ford. Palkó Gábor, Ráció, Budapest, 2010, 19-23.

10 7. 3: „Ha tehát értelmes és az irodalomban jártas ember gyakran hall valamit, de az a lelkét [a maga emelkedettségével együtt] nagyszerủ gondolatokra nem indítja, s elméjében a tüzetes vizsgálat sem hagy többet a puszta szónál, sőt, ha alaposan szemügyre vesszük, sekélyességbe hullik az egész, akkor az nem igazi fenség, hisz hatása csak addig tart, amíg hallgatjuk. Mert csak az a valóban nagy, amibe hosszasan el lehet mélyedni, s aminek nehéz, jobban mondva lehetetlen ellenállni; az emléke pedig erős, sőt kitörölhetetlen." (Figyelemre méltó ugyanakkor, hogy itt a megértés és az elidőzés hermeneutikai nyelvezetébe is belopódzik az erőszak,

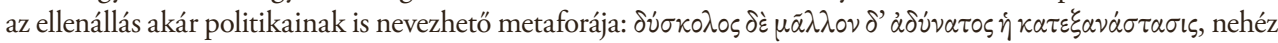
vagy inkább lehetetlen az ellenállás, sőt akár „lázadás”, „felkelés” [DE JONGE, Ps.-Longinus on Ecstasy, 155]: ott kell maradni a műnél, alávetve hatásának.) 39. 3: „Nem látjuk-e hát, hogy a szavak összefűzése valamiféle összhangja az emberrel veleszületett nyelvi készségnek, s ez magába a lélekbe kap, nemcsak hallásunkba; megindítja bennünk a megnevezések által keltett tarka képzeteket, gondolatoknak, tárgyaknak, szépségnek, jó hangzásnak gazdag formáit - mindannak, ami velünk született és bennünk felnövekedett; $s$ hangjainak változatos formájával és összeolvadásával a beszélőben felébredt affektust a közelében lévők lelkébe átviszi és a hallgatókat mindig annak részesévé teszi, a nyelvi elemek egymásra építésével a nagyszerủ hatásokat összhangba hozza, s mindezzel egyszerre megigéz és a nagysággal, méltósággal, fenséggel és mindazzal, ami benne magában is jelen van van, minket is minden alkalommal összhangba hoz, elménken teljesen felülkerekedve?” (Mi ez, ha nem a gadameri volumennek, a költemény érzéki térfogatának és apofantikus, értelemfeltáró karakterének az együttgondolása, melynek hermeneutikai eredetét még a nem hermeneutikait propagáló Gumbrecht is kénytelen elismerni [I. m., 89]? És ugyanakkor itt is megjelenik a „megigézés”

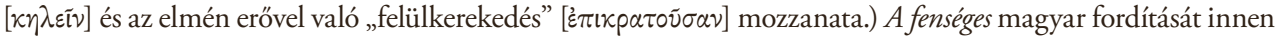
idézem, többször is, külön jelzés nélkül, módosítva: Pseudo-Longinos, A fenségröl. Görögül és magyarul, ford., bev. és jegyz. NAGy Ferenc, Akadémiai, Budapest, 1965. A görög szöveget Russell kiadása nyomán hozom: 'Longinus' On The Sublime, szövegkiadás, bev. és komm. D. A. Russell, Clarendon, Oxford, 1964.

11 Porter ezzel kapcsolatban materiális és immateriális fenségesről beszél (James I. Porter, Is The Sublime An Aesthetic Value? = Aesthetic Value in Classical Antiquity, szerk. Ineke Sluiter - Ralph M. Rosen, Brill, Leiden, 2012, 47-70; például 58-59; a materiális fenséges a[z esztétikai] tapasztalat intenzifikálását jelentené, az immateriális fenséges az anyagtól való minél tökéletesebb elkülönülést. Persze, éppen mivel mindkettő az anyaghoz való viszonyban mutatkozik meg, a legszorosabb rokonai egymásnak, és mindkettő beleillik a fenséges mint intenzitás koncepciójába, lásd Uo., 63, 66).

12 Stephen Halliwell, The Mind's Infinity. Longinus and the Psychology of the Sublime = Uö., Between Ecstasy and Truth. Interpretations of Greek Poetics from Homer to Longinus, Oxford UP, Oxford, 2011, 327-367, főleg 339-342, 363-367; egy karakteres megfogalmazás: 363-364: „The communication of the sublime is a 'communion' of minds in which truth (contact with the real) and ecstasy (moments of transformative 
jelenségről beszélek, akkor ennek az összetett hatásnak csak az egyik, az affektivitással és a nem hermeneutikai mozzanattal jellemezhető oldalát domborítom ki, amelyhez azonban a fenséges, a hüpszosz hatáskomplexumában hozzátartozik a megértés és a hermeneutikai mozzanatával leírható másik oldal is. Ehhez hasonló szerkezetet rajzol ki a fenséges kettősségben megragadható politikai hatása is, amelyben egyfelől az alávetés, leigázás, az erőszak mozzanata, másfelől a hallgató/olvasó „felemelése”, gondolkodásának „felszabadítása” is jelen van. ${ }^{13}$

3. 1. Az ekpléxisz és a hozzá kapcsolódó igei és melléknévi alakok hatszor fordulnak elő Pszeudo-Longinosz szövegében, ${ }^{14}$ egy alkalommal pedig a plésszein alak jön elő (az ekprefixum nékül), s mivel szempontunkból ez az előfordulás is hordoz tanulságokat, ezt a helyet is meg fogom vizsgálni.

A szó mindjárt az 1. caputban felbukkan, amikor Pszeudo-Longinosz arról beszél, hogy a fenséges ( $t a$ hüpszé) nem egyszerüen a stílus egy meghatározott nemét jelenti (mint többnyire a retorikai szakirodalomban, a középső és az alacsony stílusnem mellett), hanem az írás- vagy beszédművek csúcsát (akrotész, exokhé). Ezt az állítást a szerző az 1. 4-ben a fenséges, pontosabban itt az ennek szinonimájaként használt „nagyszeru”” (ta hüperphüa) ${ }^{15}$ hatásának rendkívüli voltával indokolja:

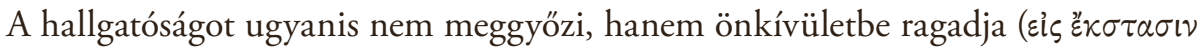

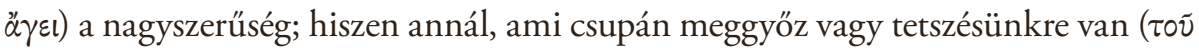

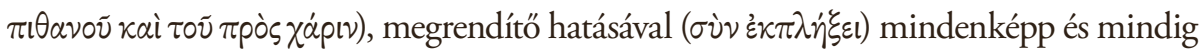

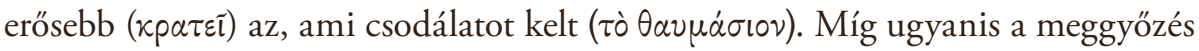
sikere nagyrészt rajtunk múlik, a nagyszerűség hatalmat és ellenállhatatlan erőt

consciousness) meet”; vagy más aspektusból: „quasi-material specifities of language and a grand sweep of vision orientated towards the whole of reality" (Uo., 328).

13 Yun Lee Too, The Idea of Ancient Literary Criticism, Clarendon Press, Oxford, 1998, 216. Too meggyőzően mutatja meg Pszeudo-Longinosz művének politikai relevanciáját (6. fejezet, 187-217: Dislocating States and the Sublimity of Criticism). Vö. például Most téves nézetével, aki szerint a fenséges területe mindig is úgy különült el, mint „the relatively harmless aesthetic or the natural rather than the potentially explosive political or ecclesiastical" (Glenn W. Most, After the Sublime, The Yale Review 90/2 [2002], 101-120; itt: 112). A fenséges az utóbbi évtizedekben is összekapcsolódott a politika szférájával, lásd erről Philip SHAw, The Sublime, Routledge, London - New York, 2006, 183-188 (Lyotard), 219-220 (Žižek).

14 A 35. 4-ben nem nyelvi hatás eredményeképpen, hanem a csillagok fenséges látványa nyomán áll elő a megrendülés, így ezt az előfordulást nem fogom vizsgálni.

15 A fogalomhasználat lazaságáról Pszeudo-Longinosznál (ami egyébként nem tér el általában az antik szónoklattani munkák szerzőiétől) lásd például PorTer, The Sublime In Antiquity, 61 (6. j.), 62, 63, 180, 182; Fuhrmann, I. m., 141. Az értekezés ránk maradt szövegének gondolatmenete a rengeteg példa, kitérő, és persze a szövegromlás miatt nem minden ponton könnyen követhető. A gondolatmenet megvilágító rekonstrukciójára lásd mindenekelőtt FuHRMAnN, I. m., 136-160. 


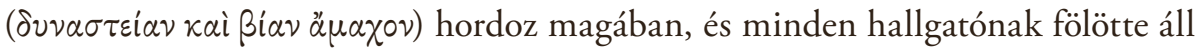

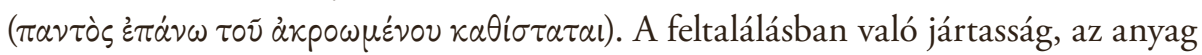
elrendezése és gazdaságos elosztása nem tűnik ki egy vagy két hely alapján, sőt az egész mủ szövetéből is csak nagy nehezen tudjuk kivenni. A fenséges azonban, ha valahol a megfelelő pillanatban megjelenik, az egész tényanyagot villámcsapásként szórja

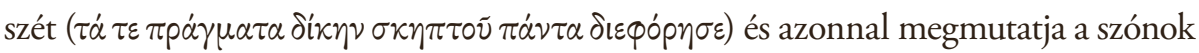

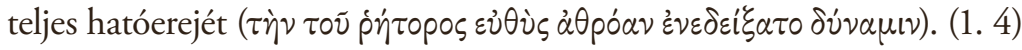

Ebben a szakaszban az ekpléxisz hatásának leírását, amely a mủ kulcsfogalmának, a fenségesnek a „meghatározásában” olvasható, az erő, erőszak és hatalom nyelve uralja. A fenséges

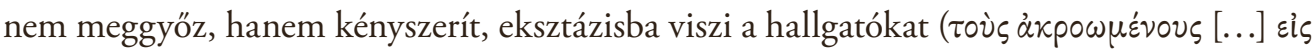

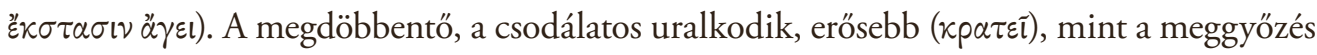

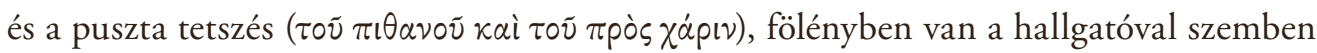

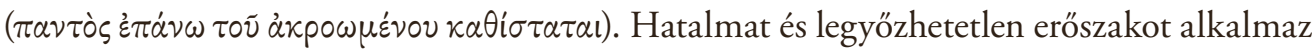

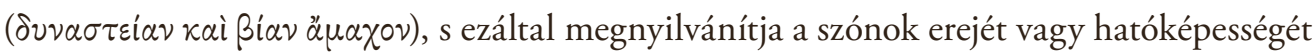

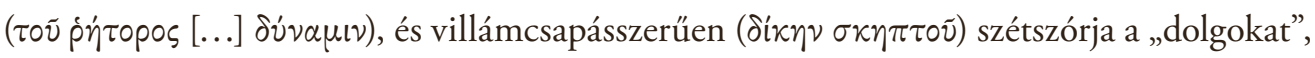
vagyis a beszédben, a racionális érvelés keretében szóba hozott tényeket $(\tau \dot{\alpha} \tau \varepsilon \pi \rho \alpha \dot{\gamma} \mu \alpha \tau \alpha$ [...] $\pi \dot{\alpha} \nu \tau \alpha \delta \varepsilon \varepsilon \varphi \dot{\rho} p \eta \varepsilon \varepsilon)$.

A szövegrész a fenséges hatásában először a csodálatos (to thaumaszion) mozzanatát különíti el, s azután ennek a csodálatosnak a hatását, hatásmódját adja meg az ekpléxisszel mint megdöbbentő és megrendítő mozzanattal. (Vagy azonos szinten összekapcsolja a kettőt?) Ez az ekpléxisz itt egyfelől az eksztasziszhoz kerül közel, másfelől a meggyőzés és a tetszés vagy gyönyörködtetés mozzanataival állítódik szembe (peithó, to pithanon, illetve to prosz kharin). Az eksztaszisz Pszeudo-Longinosz és egyáltalán a platóni hagyomány szókincsében az enthusziaszmoszhoz, az istennel eltelés, istentől való megszállottság képzetköréhez áll közel. Ennek eredménye az, hogy a költő, az előadó és a néző az alkotás és az előadás, és ugyanígy a befogadás során önmagán kívül kerül, nincs magánál (erről a legrészletesebben Platón Iónjából értesülünk).

Másfelöl az eksztaszisz és így az ekpléxisz is háttérbe szorítja a racionális meggyőzés és a gyönyörködtetés, a puszta tetszés teljesítményét. A meggyőzés, különösen is a racionális érvelés hatása nagyrészt rajtunk áll, nagyrészt a mi hatalmunkban van ( $\left.\dot{\omega} \varsigma \tau \grave{\alpha} \pi 0 \lambda \lambda \dot{\alpha} \dot{\varepsilon} \varphi^{\prime} \dot{\eta} \mu \tau \tilde{\tau}\right)$ ). Ez alighanem arra utal, hogy az ilyen érvelés meghallgatása nyomán mi döntünk arról, szuverén módon, hogy miképpen cselekszünk, például hogy miként szavazunk. ${ }^{16} \mathrm{~A}$ racionális érveknek ellen lehet állni, és nem is feltétlenül irracionálisan, hanem mondjuk egy másik, hasonlóan meggyőző racionális érvelés hatására. Ezzel szemben a fenséges (a „nagyszerü”)

16 RusseLL, I. m., 62. 
a maga csodálatosságával, megdöbbentő vagy megrendítő hatásával minden esetben fölébe

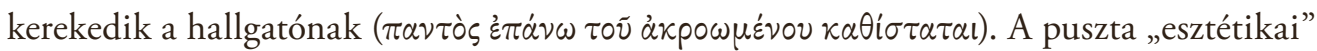
tetszés, a to prosz kharin itt valószínűleg a nyelvi részletek tetszetős kidolgozására, például a jó hangzás kellemességére vagy az érzékletes képek fölidézésére utal; az ekpléxisszel együtt (vagy általa) ható thaumaszion azonban ezt a tetszést is felülmúlja, intenzív ereje nem merül ki a tetszés gyöngébb érzületében. A dünaszteia és a bia amakhosz (hasonlóan a szakasz végén olvasható dünamiszhoz) itt a hatalomgyakorlásnak az erőn alapuló formáit jelöli (mindhárom szót használják politikai kontextusban is). ${ }^{17}$ A dünaszteia esetében ez az erő nem feltétlenül jelent erőszakot, vonatkozhat (akár a racionális érveléssel is összekapcsolható) legitim uralomra is, a bia azonban erőszakot, kényszerítést jelent, mely többnyire a meggyőzés békés eszközével áll szemben. A fenséges hatása valami elemi, ellenállhatatlan; valamiféle materiális, fizikai hatáshoz áll közel. Affekció és kogníció itt szembe van állítva egymással.

Ezt a materiális-fizikai hangsúlyt erősíti meg végül a szakasz végén olvasható kép a fenséges

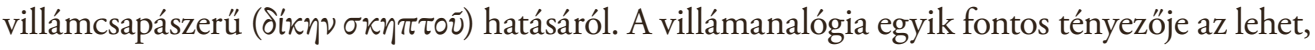
hogy a fenséges hirtelen, egy pillanat alatt, egy csapásra mutatkozik meg, egy (beszéd)mü jól időzített csúcspontján. ${ }^{18} \mathrm{~A}$ természeti kép, másfelől, újfent az embert meghaladóhoz, az ellenállhatatlanhoz kapcsolja oda ezt a hatást, valamihez, ami a maga ellenállhatatlan természeti-fizikai erejével hat a világra és az emberre. ${ }^{19}$ A $\delta є \varnothing \emptyset o ́ p \eta \sigma \varepsilon$ (széttép, szészór, elpusztít) jelentése itt nem egészen világos (a fordításban azt adtam: „A fenséges [...] az egész tényanyagot villámcsapásként szórja szét”). Talán arra utal, hogy a maga erőszakos fellépésével szétszórja, megsemmisíti, kiiktatja a megfontolás szellemi teréből az érvelés során előadott, az állítás alátámasztására felhozott tényeket, az érvelés pragmatikus kontextusát (ta pragmata). ${ }^{20}$ Valamint, szemben a heureszisz és a taxisz - a latin nyelvű szónoklattani irodalomban ez az inventio és a dispositio, a feltalálás és az elrendezés - nehezen érzékelhető voltával, a fenséges hatása villanásszerü fényével azonnal jól láthatóan megmutatkozik. A fenségesnek ez a villámcsapásszerű, erőszakos hatása, az, hogy „szétszórja a tényanyagot”, s hogy a szöveg bizonyos pontjain váratlanul bukkan fel, a fenségest nem annyira pozitív szubsztanciaként, hanem inkább szakadásként, hasadásként, vágásként, sőt sebként gondoltatja el. ${ }^{21}$

Kant $A z$ itélöerö kritikájának 28. paragrafusában (A természetröl mint hatalomról) ugyancsak használja a villám és a mennydörgés képét („az égen tornyosuló, mennydörgés és villámlás közepette tovavonuló viharfelhők”). Nála azonban a villám fenséges látványként kerül elő (ami

17 Gorgiasznál pedig, a Helené dicséretében, a logosz az, ami dünasztész megasz, nagyhatalmú úr.

18 Casper C. De Jonge, Demosthenes versus Cicero. Intercultural Competition in Ancient Literary Criticism = Eris vs. Aemulatio, szerk. Cynthia Damon - Christoph Pieper, Brill, Leiden - Boston, 2019, 300-323; itt: 314. 19 DE Jonge, Ps.-Longinus on Ecstasy, 154.

20 Russell, I. m., Introduction XXXIX és 62.

21 Porter, The Sublime In Antiquity, 61. 
persze ugyancsak implikálja a villám ellenállhatatlan természeti erejét is), melyet biztonságos helyről nézünk („feltéve, hogy mi magunk biztonságos helyen vagyunk”). A természeti fenséges itt pusztán egy közvetíto elem vagy trigger, amelyet csak azért mondunk fenségesnek, „mert a képzelőerőt olyan esetek ábrázolásáig emeli, amelyekben az elme [das Gemüt, tehát amihez nemcsak kognitív, hanem affektív képességek is tartoznak] a maga számára érezhetővé tudja tenni mivoltának [Bestimmung, rendeltésének, meghatározásának] saját, a természetnek is felette álló fenségességét." ${ }^{22}$ Pszeudo-Longinosznál ezzel szemben a villám képe a fenségesnek az írás- vagy beszédmüben átütően érzékelhető hatására vonatkozik, és szerepe közelebb van a pusztító fizikai erőhöz, amennyiben a (szövegben előadott) dolgokat a kép értelmében nem a villám látványa, hanem annak mintegy fizikai hatása szórja szét és semmisíti meg.

3. 2. Az antik retorikai hagyományban meghatározó volt a nyelv performatív, hatáselméleti megközelítése. A performativitás mozzanatát itt most elsősorban annak kidolgozásaként értve, hogy a nyelvi anyag milyen megformálásával lehet kiváltani bizonyos pathoszokat. Pszeudo-Longinosz teljesítménye talán ezeknek a lehetőségeknek, a fenséges kiváltása retorikai lehetőségeinek az elemzésében a legkiemelkedőbb. ${ }^{23}$ Nézzünk meg néhány olyan helyet, ahol az ekpléxisz közvetlenül a nyelv affektív dimenziójához kapcsolódik.

A megrendülés kiváltásának fontos lehetőségét nyújtják az úgynevezett phantasziák, melyeket Pszeudo-Longinosz a 15. fejezetben elemez. Ez a szó Pszeudo-Longinosznál először is a képzeleti képet jelenti, de mindjárt úgy, hogy ehhez mintha már eleve hozzátartozna a nyelvi ábrázolás mozzanata is: olyan belső képalkotásról (eidólopoiia), mentális (képi) tartalomról

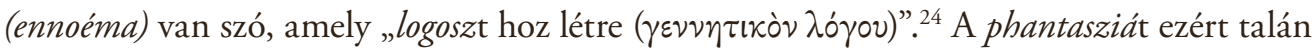

22 Immanuel Kant, $A z$ itélöerö kritikája, ford. Papp Zoltán, Ictus, h. n. [Szeged], é. n. [1997], 181-182. A német szöveg: Immanuel Kant, Kritik der Urteilskraft, szerk. Wilhelm Weischedel, Suhrkamp, Frankfurt am Main, 1995, 185-186. Lásd még a paragrafus utolsó bekezdéséből: „A fenséges tehát nem a természeti dolgokban rejlik, hanem csak elménkben, amennyiben tudatára tudunk ébredni önmagunk fölényének a bennünk lévő természettel, és ezáltal a rajtunk kívüli természettel szemben is (amennyiben ez utóbbi befolyással van ránk). Mindazt, ami bennünk ezt az érzést kiváltja - és ehhez a természet hatalma szükséges, mely erőinket felszítja -, fenségesnek nevezzük (habár nem tulajdonképpeni értelemben).” (185.) Miközben Kant itt a fenséges természet hatalmáról beszél (jóllehet nem tulajdonképpeni értelemben, hiszen a fenséges „nem a természeti dolgokban rejlik”), alapvető törekvése az, hogy kiiktassa az erőszakos mozzanatot a fenséges fogalmából. E törekvés kétértelműségéről, vagyis hogy a képzelőerő szabadságának elrablása nem önmagánál fogva fenséges, hanem csakis egy még nála is hatalmasabb "Gegen-Gewalt"-nak - az ember érzékfeletti lényegének, észképességének - az érzése által, melyet éppen a képzelőerő gyöngesége vált ki, lásd Winfried Menninghaus, Zwischen Überwältigung und Widerstand. Macht und Gewalt in Longins und Kants Theorien des Erhabenen? Poetica 23. (1991/1-2.), 1-19, itt: 6, 17.

23 A fenséges és a retorika kapcsolata a 18. században fog végérvényesen megbomlani, a fogalom „deretorizálódik", és így válik esztétikai kategóriává. Lásd erről Most, I. m., 111-114.

24 Alighanem ebben rejlik a phantaszia pszeudo-longinoszi koncepciójának eltérése a „mentális reprezentációnak" a filozófusok által intencionált általános értelmủ fogalmi tartalmától. Vö. Carlo Maria MAzzucchI, Dionisio Longino: Del sublime, Vita e Pensiero, Milánó, 1992, 206. 
képi megjelenítésnek, vizualizációnak nevezhetjük, ${ }^{25} \mathrm{~s}$ a vizualizáció itt a mentális és a nyelv által létrehozott „képi” megjelenítésre is vonatkozik. A logosz ugyanis itt valamilyen kifejezési formát, megformált nyelvi megnyilatkozást jelent. Ennek a formának a hatása a referenciális síkon abban áll, hogy azt, amiről a szónok beszél, a hallgatók számára látványként jeleníti meg. Ehhez arra van szükség, hogy a beszélő maga is „lássa”, amit mond, s ez az istentől való megszállottságnak (enthusziaszmosz) és valamiféle affektív érintettségnek (pathosz), elragadtatásnak a látomást előidéző hatására következik be (15. 1). Ezután a szerző a következő megkülönböztetést teszi: „Jól tudod, hogy másra törekszik a szónoki vizualizáció, és másra a költői, és hogy a költészetben ennek célja a megrendítés ( $\left.\varepsilon_{\kappa} \kappa \tau \lambda \eta \xi \iota \varsigma\right)$, a beszédben pedig

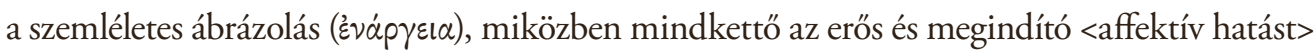

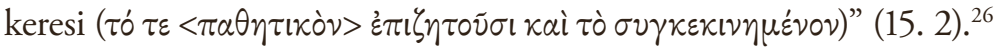

Költészet és szónoki próza szembeállítása eszerint a közvetlen nyelvi hatáson fordul meg. A költők a megrendítésre, a hallgatók megdöbbentésére, kizökkentésére törekednek, a szónokok pedig az ábrázolás részletező pontosságára, mely a meggyőzés és cselekvésre indítás szolgálatában áll. A szónoki képzelet referenciális kötöttsége erősebb, akkor is, ha ez a referenciális erő nem a valóságnak való megfelelésre, hanem inkább az elképzelhetőségre, valószínűségre, hihetőségre vonatkozik. Pszeudo-Longinosz ezt néhány bekezdéssel később világosabban is megállapítja (15. 8). Itt először is azt mondja, hogy a költőknél a vizualizációban valamiféle túlzás van jelen: a hüperekptószisz lefordíthatatlanul bonyolult összetétele magában foglalja a kiesés-kitérés, a megszokottól eltérés mozzanatát (ek-piptó), és azt is, hogy ez „túl” van (hüper) a megszokotton, tehát valamilyen fokozást. ${ }^{27}$ Azután, hogy ez a túlzás vagy szokatlanság a képi megjelenítésben mitikusabb, meseszerűbb (müthikótera), vagyis nem a hihetőség követelményéhez ragaszkodik. Majd ezzel állítja szembe a szónoki phantasziát, amely viszont akkor a legszebb, ha emprakton, a gyakorlathoz, tényszerüséghez, a cselekvés praktikus kontextusához kötődik („megvalósítható”), és ha igaz (enaléthesz). Tehát ami a költészetben és a beszédekben közös: az intenzív hatás, a hallgatóság affektív megérintése. De erősebb az, ami szembeállítja őket. Költészet versus szónoki próza: megrendítés versus szemléletesség, areferencialitás versus referenciális kötöttség, meseszerűség versus praxiskötöttség és valószerűség.

Ezek a jól elrendezett szembeállítások azonban néhány helyen mintha összezavarodnának, és egy bizonyos khiasztikus átrendeződést, vagyis keresztalakzatot mutatnának, amelyben a rögzített és szembeállított jellemzők mintha felcserélődésre is képesek lennének. ${ }^{28}$ Egyfelől

25 Így már Russell, I. m., 120; Halliwell, I. m., 348; De Jonge, Ps.-Longinus on Ecstasy, 161.

26 RusseLL, $I . m$., 122 a < $<\alpha \theta \eta \tau \tau$ เò̀ $>$ beillesztéséről azt mondja, hogy a szükséges kifejezés jelentése kétségen felül áll, noha a pontos szóban természetesen nem lehetünk biztosak.

27 Tehát egyidejűleg van jelen benne a fenségeshez kapcsolódó nómenklatúrában gyakran megjelenő $e k$ - és hüper-prefixum (az ek-és hüper-szavakhoz lásd PORTER, The Sublime In Antiquity, 181).

28 Már Russell, I. m., 121 utal arra, hogy amit Pszeudo-Longinosz itt a 15. 2-ben a kétféle hatást szembeállítva mond, azt a 15. 8-11 ismeretében nem szabad túlhangsúlyozni. Ugyanakkor a szónoki beszéd 
a költészetben is fontos a valószerüség, akkor is, ha nem referenciális azonosíthatóságról, hanem a valószerűségről mint nyelvi effektusról van szó. Az Erinnüszöket látó Oresztészt

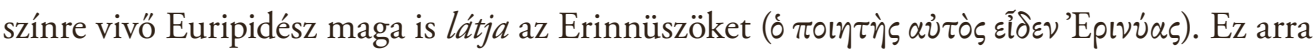
utal, hogy Pszeudo-Longinosz számára Euripidész vagy teljesen azonosul Oresztésszel, vagy úgyszólván „szemtanúként mellette áll”. ${ }^{29}$ Csakis így lehet képes arra, hogy a hallgatókat is

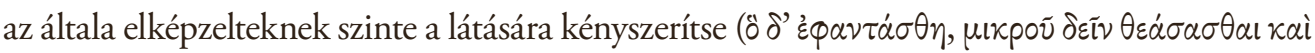

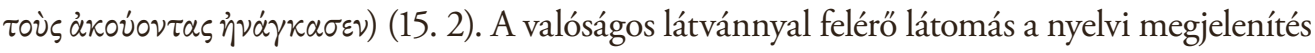
intenzitásának köszönhetően a vizualizációnak ellenállhatatlan, kényszerítő erőt ad. Hogy a nézők részéről ez a „látás” csak „kevés híján”, „szinte” történik meg, azt az magyarázza, hogy a „valóságos” látás esetén nekik is őrültnek kellene lenniük (miként az Oresztésszel azonosuló vagy hozzá „csatlakozó” Euripidésznek). ${ }^{30}$ Ugyancsak Euripidészről, az elveszett Phaethón című tragédia két részletét kommentálva állítja (retorikai kérdés formájában) Pszeudo-Longinosz, hogy a jelenetről azt lehetne mondani, hogy a költő lelke Phaethónnal együtt maga is felszállt Héliosz kocsijára, és a vakmerő ifjúval együtt vállalva a veszélyt, „együtt repült a lovakkal”. Hiszen „ha azzal az égi vállalkozással egy iramban nem rohant volna,

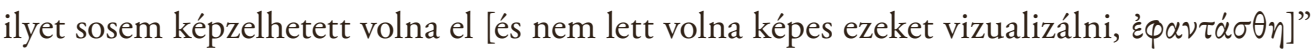
(15. 4). Itt a képzelet valószerü játéka az, ami a jelenet leírásának magával ragadó erőt ad. Nem a phantasziát tárgyaló fejezetben hangzik el, és nem is fordul elö benne a phantaszia kifejezés, de az is a költészet nagyon is valószerű hatásának hatékonyságát és így értékességét mutatja, hogy az irat szerzője Szapphó híres 31-es költeményének („Úgy tünik nékem, hogy az istenekkel / egy a férfiú” stb.; Devecseri Gábor fordítása) „leíró”, szimptomatológiai részét éppenséggel annak igazsága, valóságossága (alétheia) miatt dicséri (10. 1.), és megállapítja, hogy a szerelmesekkel valóban „ilyenek történnek” (10. 3). A valósághatás másfelől itt is a nyelvi ábrázolás kiválogató és egybefüző müveleteinek eredménye (10. 1.), vagyis a referenciális megbízhatóság követelménye nem a valóság puszta másolását várja el, hanem hatékony nyelvi megjelenítését. ${ }^{31}$ De a szemléletesség, valószerüség, a (fóként) lélektani hitelesség szempontja ebben a formában mégis müködik ${ }^{32}$ - a legtisztább lírai költészet megítélésekor is.

Hasonló átfordulást vagy keveredést figyelhetünk meg másfelől a szónoki beszédek kommentálása során is. A 15. 9-ben Pszeudo-Longinosz a szónoki phantaszia mibenlétének

erősebb valóságvonatkozását elfogadja. Látni fogjuk, hogy a szembeállításnak ez a része sem áll rendíthetetlenül. Ahogyan Halliwell fogalmaz: „even when he [Pszeudo-Longinosz] tries to distinguish 'poetic' from 'rhetorical' imagination (phantasia) in ch. 15, it is significant that his argument becomes unstable" (Halliwell, I. m., 329), és "there is a revealing equivocation in his position” (349). Fuhrmann itt is a Pszeudo-Longinosznál szokásos fogalmi hajlékonyságot, az éles fogalmi elhatárolás hiányát említi (Fuhrmann, $I . m$., 150).

29 DE Jonge, Ps.-Longinus on Ecstasy, 162.

30 Uo., 162.

31 Halliwell, $I$. m., 345.

32 Uo., 350, 362. 
példákkal történő magyarázatára tér rá. A beszédekben megjelenik a küzdelmes ${ }^{33}$ vagy drámai, effektív, involváló mozzanat (enagónia), és az is, hogy affektivitást visznek a megnyilatkozásba (empathé). Olyannyira, hogy ha a rétor phantasziajja ezeket a hatáselemeket „bele-

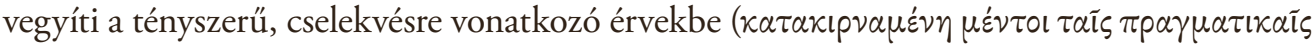
$\dot{\varepsilon} \pi \iota \chi \varepsilon\left\llcorner\eta^{\prime} \sigma \varepsilon \sigma(v)\right.$, akkor nemcsak meggyőzi, hanem le is igázza [szolgává teszi] a hallgatóságot

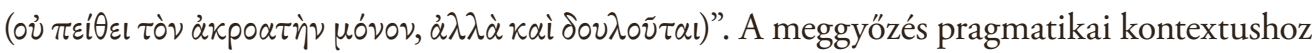
kötődő mozzanata mellett a vizualizáció elképzeltető és affektust keltő ereje a szónoki beszédben is fontos, olyannyira, hogy a mondat végén Pszeudo-Longinosz ennek a nyelvi

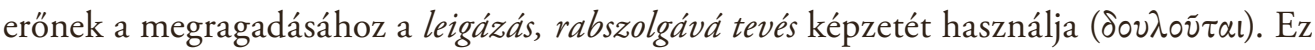
a képzet nyilvánvalóan abba a sorba illeszkedik, mint az erö, hatalom, legyözhetetlen erö(szak) föntebb, a 3. 1-ben tárgyalt figurációi (1. 4); vagy ugyanígy a hallgató magával ragadásának képei (10. 1, 16. 2, 18. 2, 22. 3, 30. 1); vagy éppen a kényszer (például az imént idézett 15. 2-ben) és egyáltalán a megmozdítás, megindítás figurációja (20. 1, 29. 2, de ugyanígy megint a fentebb idézett 15. 2-ben).

A következő bekezdésben Hüpereidésztől idézett mondat („Ezt az indítványt nem a szónok fogalmazta meg, hanem a khairóneiai csata.") ${ }^{34}$ a phantaszia redukált szerepét mutatja meg, amennyiben a „vizualizáció” itt mindössze a megszemélyesítés trópusának egy ok-okozati kapcsolaton alapuló változatát jelenti, tényleges vizualizációról nincsen szó. Mégis, a cselekedetre vonatkozó tényszerű érvelés mellett itt a szónoki vizualizáció (ó $\dot{p} \eta \dot{\tau} \omega \rho \pi \varepsilon \varphi \dot{\alpha} \nu \tau \alpha \sigma \tau \alpha \iota)$ is szerepet játszik, s ezzel az állitással a szónok átlépi a (tiszta, racioná-

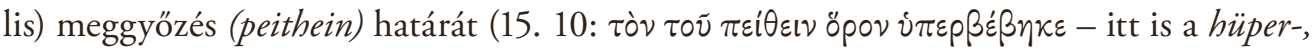
a túl- vagy átlépés transzgresszív mozzanata figyelhető meg). Ami pedig különösen figyelemreméltó, az az, hogy Pszeudo-Longinosz, ha nem is expressis verbis, de szóhasználatából kikövetkeztethetően, ezt a határátlépést kedvezően értékeli. Ezt mondja: „S mindebben

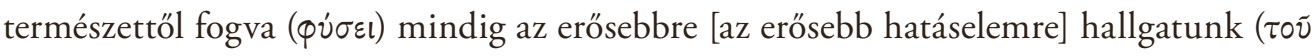

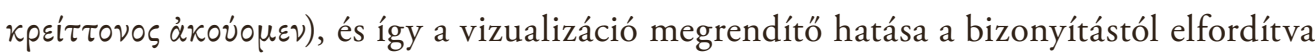

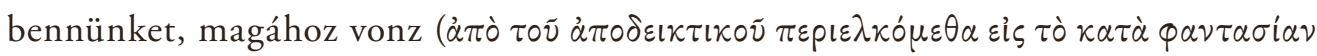

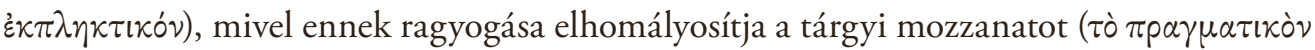

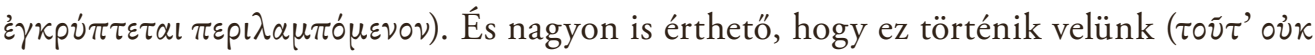
$\left.\dot{\alpha} \pi \varepsilon ı x^{\prime} \tau \omega \varsigma \pi \dot{\alpha} \sigma \chi 0 \mu \varepsilon v\right)$, mert ha két elemet összekapcsolunk, akkor közülük az erősebb

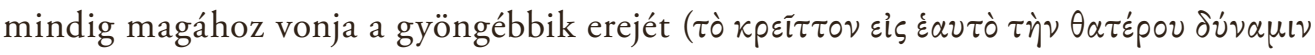
$\pi \varepsilon p ı \sigma \pi \tilde{\alpha}) . "(15.11)$ Racionális érvelés, meggyőzés és affektív hatás (megrendülés) itteni szembeállítása az 1. 4. föntebb bemutatott mintázatát követi: az ekpléxisz fölényben van

33 A fenséges agonisztikus karakterének politikai konnotációihoz lásd Too, I. m., 214-215.

34 II. Philipposz khairóneiai győzelme után (Kr. e. 338.) Hüpereidész a rabszolgák felszabadítását javasolta, erre vonatkozik a mondat. Vö. Rutilius Lupus 1. 19; Psz.-Plutarkhosz, A tíz szónok élete 849A; Russell, I. m., 125-126. 
a peitheinnel szemben. Pszeudo-Longinosz ezt a szónoki beszéd esetében is érthetőnek vagy

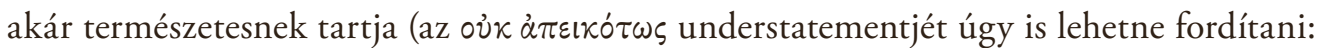
nagyon is természetes), amennyiben a beszédműveknél mindig az erősebb hatásmozzanat kerekedik felül. Ez a határátlépés, az ábrázolás és a racionális meggyőzés, a tényszerűen bebizonyított igazság határának átlépése - ha jól értem az irat szerzőjét - itt egyáltalán nem kap leértékelő hangsúlyt. Ekkor viszont annak tükörképét kapjuk meg, amit föntebb a költészet esetében láttunk: ahogyan ott a megrendítő hatás mellett (vagy annak egy elemeként) a valószerűség, hihetőség és az igazság (a referenciális kötöttség) is szerepet kap, úgy a szónoklat esetében a tárgyilag érvelő meggyőzés és az ügy konkretizálását célzó szemléletes ábrázolás (enargeia) mellett a megrendítő affektív komponens is fontos, és ez utóbbi a phantaszia teljesítményeként ragadható meg, akár egyetlen trópus alakjában is, ahol maga a vizualizáció föltehetőleg csak redukált módon működik. ${ }^{35}$

3. 3. A phantaszia tehát a nyelv fenomenális vagy megjelenítő erejének köszönhetően fejti ki a maga megrendítő hatását. Ez után nézzünk meg néhány olyan helyet, ahol a nyelvi materialitás nem szemantikai komponenseinek játékba hozása váltja ki az affektív intenzitást, melynek csúcspontja az ekpléxisz.

Hüpereidész és Démoszthenész összehasonlításából (34. 4) a korábban mondottak (villám)fényében most a Démoszthenészt jellemző rendkívüli nagyszerűség képzetét,

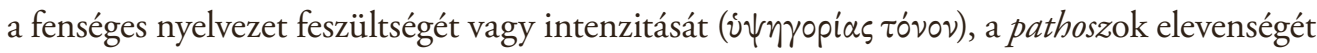

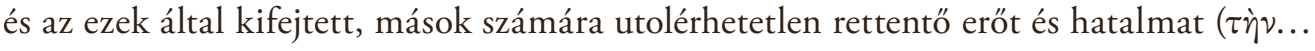

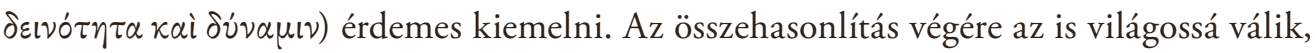
hogy Démoszthenésznek ezek az isteni adományai eredményezik azt, hogy „mindama

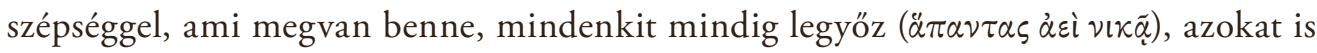
pótolva, amelyekkel nem rendelkezik, és mintegy mennydörgéssel és villámmal sújtja

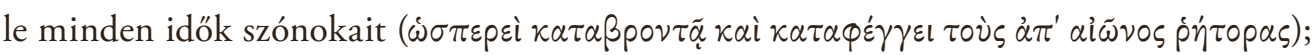
hamarabb lenne képes bárki a cikázó villámokkal szembenézni, mint tekintetével állni

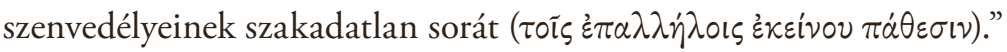

A mennydörgés és a villámfény, melyekkel mintegy elnémítja és elhomályosítja a többi szónokot (szó szerint „lemennydörgi és levillámozza” őket), Démoszthenész kanonikus helyének korokon átívelő biztosságát jelzik. De ami fontosabb: ezek a képek közvetlenül a démoszthenészi nyelv affektív hatásaihoz kapcsolódnak. Annak az ellenállhatatlan erőnek a metaforikus megjelenítését szolgálják, amelyet a szakasz korábbi része a fenség és az affektusok terminologikusabb nyelvén mutatott be, amikor arról beszélt, hogy Démoszthenész

35 Pathosz és meggyőzőerő, tkp. „hihetőség” (piszton, axiopisztia) összekapcsolásához lásd még: 16. 2, 18.1 (Démoszthenész), 38. 3 (Thuküdidész). 
„magáévá tette a legnagyszerűbb tehetségnek egészen a tetőfokig tökéletesített erényeit,

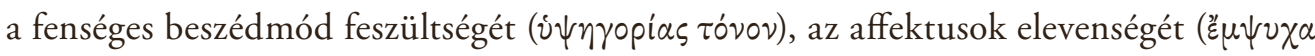

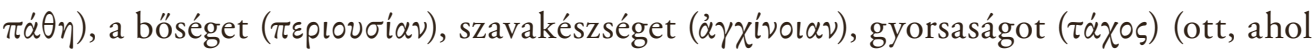
erre van szükség), a senki mástól el nem ért félelmetes erőt és hatásosságot ( $\delta \varepsilon เ \nu o ́ \tau \eta \tau \alpha$

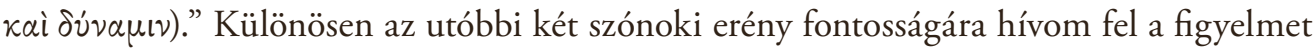
- mindkettő az erő, hatalom képzetein alapuló fogalmi metafora: a dünamisz maga erőt, hatalmat jelent, a deinotész pedig ugyanezt az erőt, ennek félelmetességét, rendkívüliségét, intenzitását emeli ki.

Cicero és Démoszthenész hasonló szünkriszisze során (12. 4-5) az athéni szónokhoz

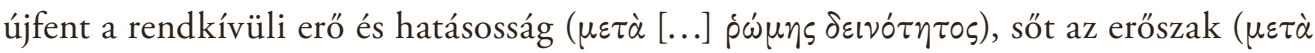
ßías) társul. ${ }^{36}$ Ezek a kifejezések többször is elöfordulnak $A$ fenséges szövegében, magának a fenségesnek a hatásával, vagy az azt elérő szerzővel összefüggésben. ${ }^{37}$ Ezen kívül pedig a fellángoló és mindent lángba borító tűz képe mellett megint megjelenik a villám és a mennydörgés is: „[Démoszthenész] mennydörgéshez és villámhoz hasonlítható ( $\sigma \kappa \eta \pi \tau \tilde{\omega}$

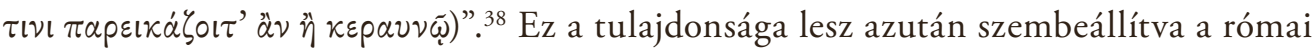
szónok „tovaterjedő lángjával”, amely „mindenfelé szétárad és elharapódzik, hosszan tartó és szüntelenül erős a tüze” (12.4). Ez után, még mindig a Ciceróval való összevetés részeként, következik az a mondat, amelyben Démoszthenész szónoki erényei kifejezetten az ekpléxisz hatásmozzanatához kapcsolódnak:

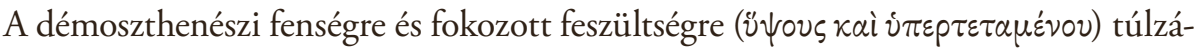

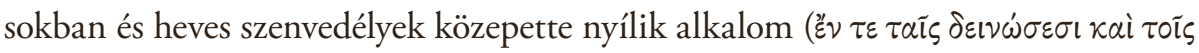

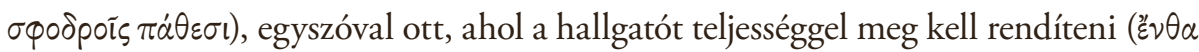

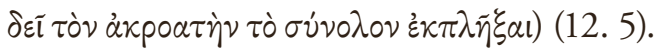

A Démoszthenészre jellemző fenség mindenekelőtt a nyelvi feszültséghez, sőt túlfeszítettséghez kapcsolódik. Ez az intenzitás főként az erős affektusok esetében, emocionálisan felfokozott nyelvezetben juthat érvényre, ott, ahol az ekpléxisz teljes hatóerejére van szükség. Ezen a helyen is világos, hogy az ekpléxisz nem egyike a szónok által a hallgatóknak

36 A két szónok összevetésének nagy hagyománya volt az antik retorikai és kritikai irodalomban (ez a hagyomány magára Ciceróra nyúlik vissza), ahol a szónoki-irodalmi teljesítmény egyszersmind a görög és a római világ közötti kulturális kompetíciót is jelentette (DE JonGE, Demosthenes versus Cicero, 304).

37 bia: 1. 4; takhosz (gyorsaság): 34. 4; deinosz és deinotész: 10. 1, 22. 3, 34. 4; DE JONGE, Demosthenes versus

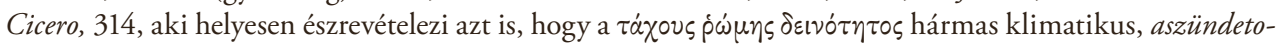
nos kólonja egyben mimetikus versengés is Démoszthenész fenséges stílusával, ahogyan az egész mondat felépítése pedig Cicerót imitálja (315).

38 Démoszthenészről szólva már maga Cicero is ama nevezetes cikázó villámokról beszél ( $A$ szónok 234: vibrarent fulmina illa). 
a maga oldalára állítása érdekében kiváltandó sajátos, helyzetfüggő affektusoknak (mint amilyen mondjuk a harag vagy a félelem), hanem valamiképpen a nyelvi hatás egészének intenzitására, megdöbbentő, felkavaró, megrendítő voltára - az igazi fenségesre - utal. Ez összhangban van azzal a sajátossággal, hogy a szerző magát a fenségest sem köti valamely meghatározott pathoszhoz, hanem ez egyáltalán a nyelvi intenzitást, az intenzív hatást jelenti nála. ${ }^{39}$

Ahhoz, hogy nyelv és affektivitás kapcsolatának elevenségét és sokrétüségét érzékeltessük Pszeudo-Longinosz értekezésében, érdemes a nem szemantikai, hanem szintaktikai alakzatokhoz, vagyis a beszéd figuráihoz fordulnunk (a szkhématához és nem a tropoihoz). A nyelvnek ezekben a nem szemantikai (de a szemantikumot természetesen befolyásoló) komponenseiben mutatkozik meg ugyanis a leglátványosabban az a kapcsolat, amelyet a szerző az affektusok és a nyelvi materialitás között feltár. Maga az ekpléxisz fogalom ezen alakzatok tárgyalásakor csak egy helyen, a hüperbatonoknál fordul elő, de a többi alakzat tárgyalásának nyelvhasználata alapján joggal következtethetünk arra, hogy PszeudoLonginosz ezeknél is számol olyan fajta hatással, mint amelyet a hüperbatonok esetében az ekpléxiszben ragad meg.

Pszeudo-Longinosz a hüperbatonok tárgyalásánál is egy összehasonlításból indul ki, Thuküdidészt veti össze Démoszthenésszel (22. 3-4). Thuküdidész merészebben jár el az összetartozó szavak és szintaktikai egységek felbontásában, de ez Démoszthenész beszédeire is erősen jellemző. Ezzel az eszközzel Démoszthenész a rögtönzött beszéd benyomását kelti, s fóként harciasságot sugall, vagy - ezt is jelentheti a kifejezés -

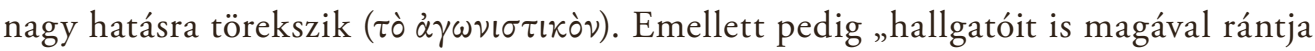

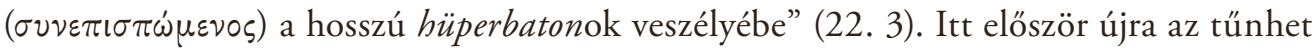
fel, hogy a kép a fizikai erőszakot vonja be a hatás leírásába: $\sigma \nu \nu \varepsilon \pi \iota \sigma \pi \alpha \dot{\omega}$ azt jelenti, hogy magával ragad, magával ránt, illetve, a szó szerinti jelentéstől némiképp eltávolodva: megnyer magának. ${ }^{40}$ Még érdekesebb azonban, hogy az itt szóba jövő hatáskapcsolatot nyelv és affektus között Pszeudo-Longinosz nem valamely referenciális vagy fenomenális elemnek tulajdonítja (ahogyan például Arisztotelész jár el Rétorikájának második könyvében az affektusok tárgyalásakor), hanem magának a beszéd specifikus modalitásának, a beszéd (szó)határokat átlépő, a köznapi vagy megszokott szórendet felforgató sajátosságának. Ennyiben itt nem az olvasottak „fiktív világába” történő belemerülésnek (az immerziónak vagy esztétikai identifikációnak) van szerepe, hanem kifejezetten a nyelvi

39 Porter, Is The Sublime An Aesthetic Value?; és ugyanígy később az antik fenségesről írott hatalmas monográfiájában (The Sublime In Antiquity, passim).

$40 \mathrm{Az}$ egész szakaszban, ahogyan az egész mủben is, hatáselméleti szempontból nagyon fontosak a szün- elötaggal képzett igék; ezek arra utalnak, hogy a szerzö a szöveg közvetítésével teszi magával együtt a fenséges intenzitásának részesévé a hallgatót (vagy olvasót); lásd erről DE JoNGE, Ps.-Longinus on Ecstasy, 170. 
materialitás affektív hatásának. ${ }^{41} \mathrm{Az}$ itt szóba jöhető és néhány sorral lejjebb meg is nevezett affektus a veszélyhez köthető félelem vagy rémület lehet (phobosz). A hallgatót azonban itt nem a beszédben ábrázoltak, hanem a szintaxis rendezetlen, kiszámíthatatlan és így veszélyesnek látszó volta kavarja fel és rémíti meg ( ahol az $\dot{\mu} \mu \alpha \lambda \lambda \dot{\omega} \nu$ agresszivitása is fontos: félelembe dobja, beledobja, beleveti a félelembe a hallgatót). A beszéd vagy a mondat (logosz) teljes szétesésének fenyegető lehetősége, az értelem kínzó felfüggesztődése $(\grave{\alpha} \nu \alpha \kappa \rho \varepsilon \mu \alpha \dot{\alpha} \sigma \alpha)^{42}$ és elhalasztódása, az átláthatatlanság és kiszámíthatatlanság az, ami itt a hallgatót rémületbe ejti.

A szónok a mondatrend felforgatásával arra kényszeríti hallgatóját, hogy „a feszültségteli küzdelem hatására a beszélővel együtt legyen részese a veszélynek” (

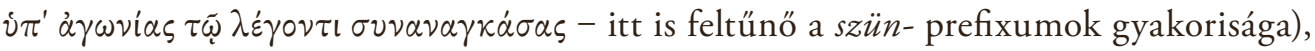
egészen addig, amíg a szónok „váratlanul, hosszú idő elteltével, végül a megfelelő pillanatban mégiscsak megadja a rég áhított megoldást”. Mindennek pedig az lesz a hatása, hogy „magával a hüperbatonok vakmerő szédületességével még sokkal jobban megren-

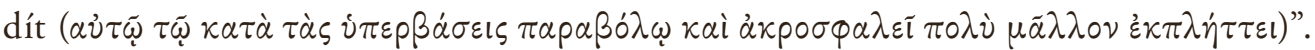
A kockázat, veszély, ingatagság képzetei - amelyekhez az erőszak mozzanata társul,

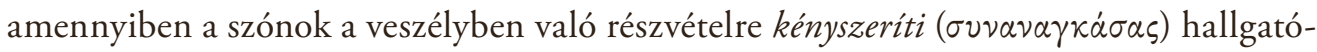
ságát - az ekpléxiszhez itt alighanem erősebben a megdöbbenés, visszahőkölés és végül talán még a megkönnyebbülés affektusait társítják (a megkönnyebbülés akkor jöhet játékba, amikor a szónok az utolsó pillanatban a régen várt szót mintegy „megtalálva” beleilleszti a beszédébe). Ami ezt a komplex hatást kiváltja, az a szórend felforgatásának,

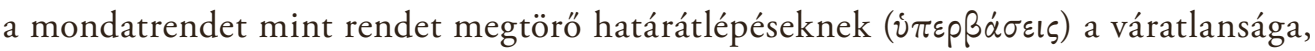

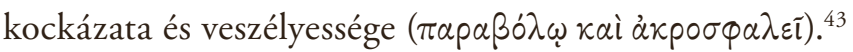

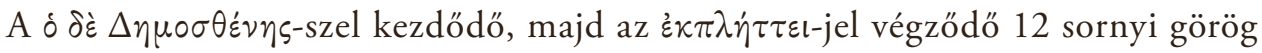
óriásmondat ${ }^{44}$ felépítésében (amelyet a fordítások rendre több mondattal adnak vissza)

41 Porter, The Sublime In Antiquity, 126; de Jonge, Ps.-Longinus on Ecstasy, 151, 167, 170-171.

42 Russell, $I . m ., 139$.

43 Mindebben a nyelvi által előidézett lelki mozgást, a felforgatott szórendnek a lélek „felforgatásaként” beteljesülő hatását hangsúlyozza DE Jonge, Ps.-Longinus on Ecstasy, 168.

44 Kísérletképpen: „Démoszthenész viszont nem annyira öntörvényü, mint amaz [Thuküdidész], de ennek az alakzatnak minden változatában rendkívül szertelen, és a szavak áthelyezésével feszültségtelinek mutatkozik és a rögtönzött beszéd benyomását kelti, ráadásul a hallgatóságot is magával rántja ( $\sigma \nu v \varepsilon \pi ı \sigma \pi \omega ́ \mu \varepsilon v o \varsigma)$ a hosszú hüperbatonok veszélyébe; gyakran ugyanis azt a gondolatot, melynek kifejtésébe fogott, felfüggeszti

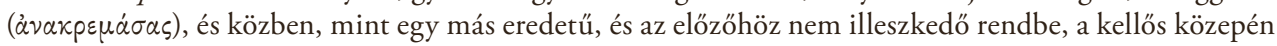
egyik dolgot a másik után, valahonnan kívülről beleforgatja, abba a félelembe rántva a hallgatót, hogy a beszéd teljesen szétesik, és arra kényszeríti őt, hogy a feszültségteli küzdelem hatására a beszélővel együtt

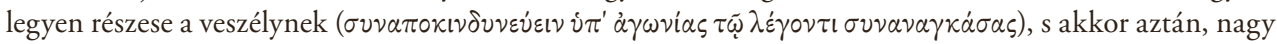
sokára és kiszámíthatatlanul, de épp a megfelelö pillanatban célhoz érve a régen keresett szót mégiscsak megadja, és magával a hüperbatonok vakmerő szédületességével még sokkal jobban megrendít ( $\alpha$ ¿ $\tau \tilde{\omega} \tau \tilde{\omega}$

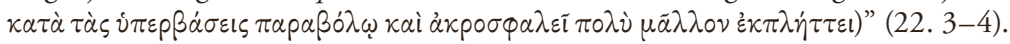


azt az önreflexív, egyszerre imitatív és performatív eljárást is bravúrosan megvalósulva látjuk, amelyet Pszeudo-Longinosz kritikai imitációjának nevezhetünk: A fenséges szerzője az általa éppen leírt démoszthenészi nyelvhasználatot a saját nyelvhasználatában utánozza vagy megvalósítja. ${ }^{45}$ Ilyen módon a mondatban a beszélés módja (die Art des Sprechens), a mondás hogyanja (die Weise des Gesagtseins, das Wie des Gesagtseins) közvetlenül tükrözi vagy megvalósítja azt, amiről a mondat beszél. A hermeneutikai hagyományból származó fogalom itteni alkalmazását indokolhatja az is, hogy a mondás milyensége Heideggernél elsősorban a beszéd diszpozicionális karakterére utal. ${ }^{46}$ Gadamernél pedig - már a művészi beszéd körét kitüntetve - a „kimondás milyensége (das Wie des Gesagtseins)” és a „tárgyi tartalom” önmagukat mint absztrakt összetevőket megszüntetve olvadnak egybe abban az „abszolút jelenlétben (zu so absoluter Präsenz)”, amelyben a „mondó szó (das sagende Wort)” tényleges "léthatalma és a beszéd tartalmi ereje (die Seinsmacht des Wortes und die Sachgewalt der Rede)" érvényre jut. ${ }^{47}$ Pszeudo-Longinosz szövegének olvasója így maga is átélheti azt az affektív hatást, amelyet az értekezés szerzője leír, éppen annak az alakzatnak az eredményeképpen, amelynek a mondat a jelentett szintjén is ezt a hatást tulajdonítja.

3. 4. Végül egy olyan helyről essen szó (20. 1-3), ahol Pszeudo-Longinosz Démoszthenész Meidiasz ellen mondott beszédének egy helyét elemzi (In Midiam 72). A beszéd kiemelkedő

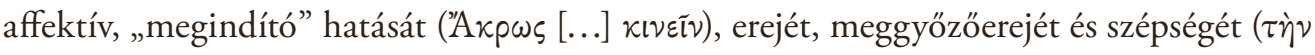

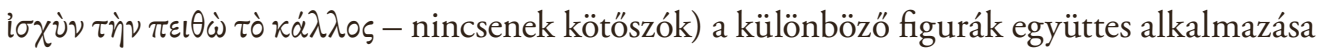
eredményezi, fóként az aszündetonok (kötőszóelhagyások) anaphorákkal és diatüpószisszal (eleven, részletező leírással) való összekapcsolása. Démoszthenész beszédében bántalmazásról, vagyis ütésekről van szó, és $A$ fenséges szerzője az „ütés” (plésszein, pléxisz) referenciájában és

45 A hüperbaton hatásáról, a phüsziszt utánzó tekhné kérdésére is kitérve (vö. 22. 1. a szenvedély önkéntelen, természetes megnyilvánulásának tudatos nyelvi imitációjáról), valamint Pszeudo-Longinosz említett imitatív eljárásáról lásd MAZzucchI, I. m., 223-224; a tárgyalt szerzőkkel való „versengésről”: DE JoNGE, Demosthenes versus Cicero, 301. Pszeudo-Longinosz imitatív stílusát már Portustól (16. század) kezdve Boileau-n át Pope-ig sokan észrevették (Porter, The Sublime In Antiquity, 63. [10. j.]).

46 Ehhez két idézet a Lét és idő nyelv-fejezetéből (34. \$): „A diszpozicionális benne-lét beszédhez tartozó megnyilvánulásának nyelvi mutatója a hanghordozásban, a modulációban, a beszéd tempójában, a »beszélés jellegében " ("in der Art des Sprechens") van. A diszpozíció egzisztenciális lehetőségeinek közlése - azaz az egzisztencia feltárása - a »költőii beszéd sajátlagos céljává válhat.”; „A beszéd amiről-jének »természetes« hallásakor persze egyúttal azt a módot is képesek vagyunk hallani, ahogyan a mondás megvalósult (die Weise des Gesagtseins), képesek vagyunk hallani a »dikciót«, de ez is csak úgy lehetséges, hogy előzőleg ezzel együtt értjük (in einem vorgängigen Mitverstehen) azt, amit beszélnek; mert a mondás módját (das Wie des Gesagtseins) csak úgy értékelhetjük, ha felmérjük, hogy megfelel-e a beszéd tematikus amiröl-jének." Martin Heidegger, Lét és idó, ford. Vajda Mihály et al., Osiris, Budapest, 2001, 193, 195. Az utóbbi helyen a fordítást módosítottam, lásd Sein und Zeit, Max Niemeyer, Tübingen, 1967, 162; 164.

47 Hans-Georg Gadamer, A szó igazságáról, ford. Poprády Judit = Uö., A szép aktualitása, T-Twins, Budapest, 1994, 111-141; itt: 130-131; Uö., Von der Wahrheit des Wortes = Uő., Gesammelte Werke Bd. 8. Ästhetik und Poetik I. Kunst als Aussage, J. C. B. Mohr (Paul Siebeck), Tübingen, 1993, 37-57; itt: 49-50. 
trópusában bravúrosan kapcsol össze három szintet: a referenciálisat, a retorikait és az affektív hatásét. ${ }^{48} \mathrm{Az}$ első aszündetonok, amelyeket Pszeudo-Longinosz idéz, azokat a módokat kötik, illetve nem kötik össze, ahogyan a támadó, a másikat megsértő-,megütő” fél (ó $\tau \dot{\tau} \pi \tau \omega \nu)$

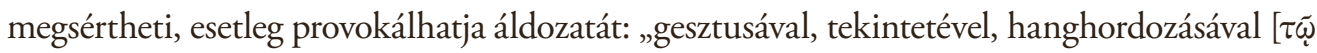
$\sigma \chi \eta \dot{\eta} \mu \alpha \tau \iota \tau \tilde{\omega} \beta \lambda \lambda_{\varepsilon} \mu \mu \alpha \tau \iota \tau \tilde{\eta} \varphi \omega \nu \tilde{\eta}$ - kötőszók nélkül]”. Pszeudo-Longinosz ezután így folytatja:

Ezután pedig, azért, hogy a beszéd egyazon kerékvágásban haladva ne álljon meg (mert a megállásban mozdulatlanság és nyugalom van, az affektus viszont a szabályozatlanságban rejlik, mivel ez a lélek mozgása és teljes felindultsága), nyomban újabb aszündetonokba és epanaphorákba csap át: „Gesztusával, tekintetével, hanghordozá-

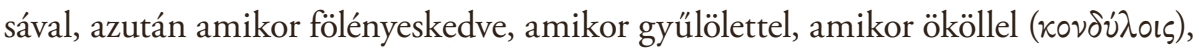
amikor pofonvágva [üti meg a másikat].” Ezekkel az alakzatokkal a szónok pontosan

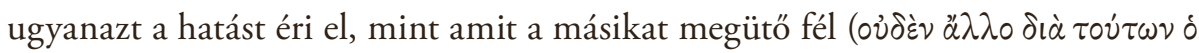

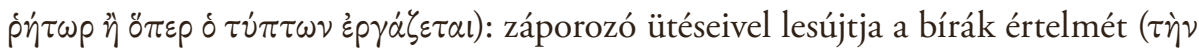

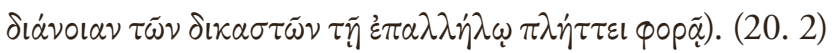

Az utolsó mondat analógiába állítja a támadót és a szónokot, valamint az áldozatot és a bírákat. A kapcsolóelem az analógiákon belül és a két analógia között az ütés lesz. A támadó fizikai ütést mér áldozatára (a kondülosz magát az ökölt és az ökölcsapást is jelentheti), a szónok pedig a kötőszók elhagyásával ütésszerüen csapja oda az egyes szavakat a bírók arcába - ő is üt, ha átvitt értelemben is, csapást mér a bírák értelmére, ítélőképességére $(\tau \grave{\eta} \nu \delta\llcorner\alpha \dot{\nu} \circ \iota \alpha \nu \tau \tilde{\omega} \nu \delta เ \kappa \alpha \sigma \tau \tilde{\omega} \nu \ldots \pi \lambda \hat{\eta} \tau \tau \varepsilon \iota)$. Ahogyan erről már volt szó, az ütés szó (az ütés metafora) jelen van az ek-pléxisz szóban is. És azt is láttuk korábban, ahogyan ehhez az átvitt értelmű kifejezéshez mégis milyen erősen tapadnak az anyagi-fizikai hatásnak, az erőnek és erőszaknak a képei. Pszeudo-Longinosz nyilvánvalóan tudatosan használja ki a két szó közötti kapcsolatot, vagyis amikor pléxiszről és plésszeinről beszél, akkor ekpléxiszre is gondol, és fordítva: az ekpléxiszt azért használhatja a szónoki beszéd vagy a költői mü elementáris, kvázi-materiális/fizikai hatásának megjelölésére, mert ott hallja benne az ütés jelentését, ennek közvetlen fizikai megjelenését vagy hatását - megtestesült metaforaként. ${ }^{49}$ És a jól kivitelezett ütés megrendito”.

48 Ezek közül a beszélő affektív állapotának és a szórend felforgatásának (ataxia) tükörszerủ kapcsolatát (ami másfelől a hallgató felindultságát eredményezi), említi PorTer, The Sublime In Antiquity, 126 és DE Jonge, Ps.-Longinus on Ecstasy, 157-158 is.

49 Vö. DE Jonge, Ps.-Longinus on Ecstasy, 158 (vö. a Szapphó nyelvének leírásához használt testies metafo-

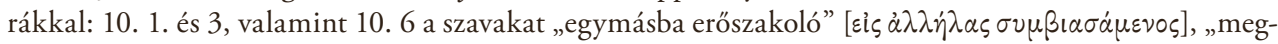

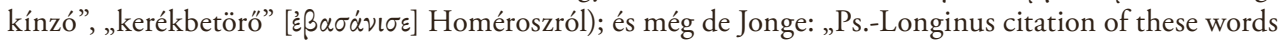
in a treatise on rhetorical ecstasy suggests a parallel between the ecstatic effects of deeds and the ecstatic effects of words." Ennek a párhuzamnak pedig, ahogyan fent megmutattam, nyelvi motivációja (is) van. 


\section{4. Összegezés}

Alighanem ebből a nyelvi kapcsolatból, Pszeudo-Longinosz etimologizáló és kritikai, vagyis költői hallásából érthető meg az, hogy a fenséges hatásának egyik mozzanatát, a nem-hermeneutikait, az affektívet, a pillanatnyit és intenzívet éppen ezzel a szóval, az ekpléxisszel jelölte meg. Nyelvnek (vagy legalábbis a szónoki vagy rhapszódoszi vagy színházi előadásnak) és affektivitásnak ezt a metszéspontját persze már a korábbi hagyományban is gyakran nevezték meg ezzel a szóval, ahogyan ezt Gorgiasz, Platón és Arisztotelész példáján láttuk. Pszeudo-Longinosz a szövegek megrendítő hatásához az erő, erőszak és hatalom képzetét kapcsolja hozzá, és ezt a hatást erősebbnek tartja a meggyőzésnél (peithein) és a puszta (esztétikai) tetszésnél (kharisz) (1. 4). Elemzésében a fenséges hatása - a villáméhoz hasonlóan - valami elemiként, ellenállhatatlanként mutatkozik meg; valamiféle materiális, fizikai hatáshoz áll közel. A költői és a szónoki phantaszia szembeállítása során azt tudjuk meg, hogy az ekpléxiszt eredményező költői vizualizáláshoz is hozzákapcsolódik a valószerűségnek, hitelességnek és így a referencialitásnak és praxiskötöttségnek a mozzanata. Másfelől pedig a szónoki beszéd céljaként megjelölt meggyőzésnek és az eleven ábrázolásnak is célja a megrendítés (15). A kezdeti szembeállítás instabillá válik. Hüpereidész és Démoszthenész összehasonlításából (34. 4) a villám-kép újbóli megjelenésén túl a dünamisz és a deinotész emelhető ki: ezek a fogalmak az erőt, hatalmat s ennek félelmetességét, rendkívüliségét, intenzitását hangsúlyozzák. Cicero és Démoszthenész összevetése során (12.4-5) az athéni szónokhoz újfent a rendkívüli erő és hatásosság, sőt az erőszak ( $\mu \varepsilon \tau \grave{\alpha} \beta i$ as) képzete társul (a villám képével együtt). A Démoszthenészre jellemző fenség mindenekelőtt a nyelvi feszültséghez, sőt túlfeszítettséghez kapcsolódik. Ez az intenzitás főként az erős affektusok esetében, emocionálisan felfokozott nyelvezetben juthat érvényre, ott, ahol az ekpléxisz teljes hatóerejére szükség van. Ezen a helyen világossá válik, hogy az ekpléxisz nem egyike a szónok által a hallgatóknak a maga oldalára állítása érdekében kiváltandó sajátos, helyzetfüggő affektusoknak, hanem valamiképpen a nyelvi hatás egészének intenzitására, megdöbbentő, felkavaró, megrendítő voltára - az igazi fenségesre - utal. Ez összhangban van azzal, hogy a szerző magát a fenségest sem köti valamely meghatározott pathoszhoz, hanem ez egyáltalán a nyelvi intenzitást, az intenzív hatást jelenti nála. Nyelv és affektivitás kapcsolatának különösen figyelemreméltó példáit kínálja a nem szemantikai, hanem szintaktikai alakzatoknak, vagyis a beszéd figuráinak tárgyalása. Itt mutatkozik meg a leglátványosabban az a kapcsolat, amelyet a szerző az affektusok és a nyelvi materialitás között feltár. A büperbatonok hatásának tárgyalása során újra előkerül a fizikai erőszak képe (22. 3). Még érdekesebb azonban, hogy az itt szóba jövő hatáskapcsolatot nyelv és affektus között Pszeudo-Longinosz nem valamely referenciális vagy fenomenális 
elemnek tulajdonítja, hanem magának a beszéd specifikus modalitásának, a beszéd (szó) határokat átlépő, a köznapi vagy megszokott szórendet felforgató sajátosságának. Ami ezt a komplex hatást kiváltja, az a szórend felforgatásának, a mondatrendet mint rendet megtörő határátlépéseknek a váratlansága, kockázata és veszélyessége: ez eredményezi az ekpléxiszt. Pszeudo-Longinosz fogalomhasználatának és elemző módszerének eredetisége mindenekelött abban van, ahogyan az affektív hatást kifejezetten és részletező elemzések révén szorosan a nyelv egészen apró komponenseihez, a szórend felforgatásához, sőt adott esetben a nyelvi hiányokhoz (a-szündeta) köti mint a nyelvi materialitás (másfelöl éppenséggel a legteljesebb immaterialitás) nem fenomenális, de nagyon is hatékony mozzanataihoz. Ennek leglátványosabb példáját ugyancsak Démoszthenésznél találja meg A fenséges szerzője, s ezen a helyen (20.2) az is világossá válik, hogy a megrendítés/ megrendülés kvázi-fizikai, erőszakos hatásának kifejezésére használt szóban (ek-pléxisz) a szerzővel együtt hallanunk kell a megrendítő ütést is (pléxisz). 